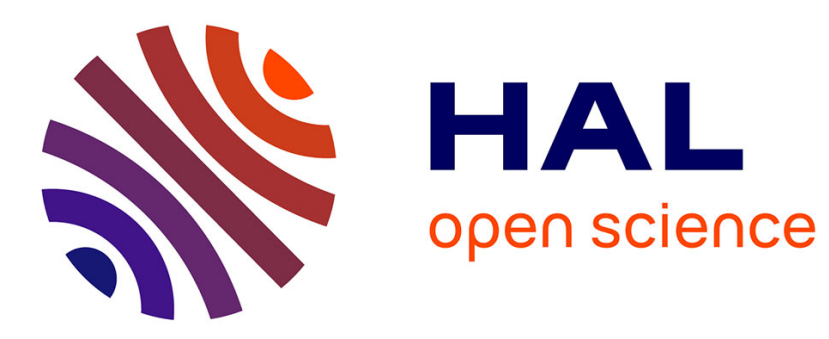

\title{
Glutenophilia: Chemistry and Flour Quality in Nineteenth-century France and Great Britain
}

Maxime Guesnon, Arnaud Page

\section{To cite this version:}

Maxime Guesnon, Arnaud Page. Glutenophilia: Chemistry and Flour Quality in Nineteenth-century

France and Great Britain. Ambix, 2021, pp.1-20. 10.1080/00026980.2021.1983696 . hal-03376883

\section{HAL Id: hal-03376883 \\ https://hal.science/hal-03376883}

Submitted on 13 Oct 2021

HAL is a multi-disciplinary open access archive for the deposit and dissemination of scientific research documents, whether they are published or not. The documents may come from teaching and research institutions in France or abroad, or from public or private research centers.
L'archive ouverte pluridisciplinaire HAL, est destinée au dépôt et à la diffusion de documents scientifiques de niveau recherche, publiés ou non, émanant des établissements d'enseignement et de recherche français ou étrangers, des laboratoires publics ou privés. 
Article to be published in Ambix: The Journal of the Society for the History of Alchemy and Chemistry, vol. 68, $\mathrm{n}^{\circ}$ 4, 2021.

\title{
Glutenophilia: chemistry and flour quality in nineteenth-century France and Great Britain
}

\author{
Maxime Guesnon \& Arnaud Page
}

Maxime Guesnon is a $\mathrm{PhD}$ student at the Centre Alexandre Koyré in the Ecole des Hautes Etudes en Sciences Sociales, Paris. He works on the history of bread in France, and studies both its physical transformations and controversies about its qualities (19th-20th centuries).

Arnaud Page is Associate Professor of British History at Sorbonne University. His work focuses on the history of both plant and human nutrition, and in particular on the role of nitrogen (19th-20th centuries).

\begin{abstract}
This article analyses how gluten was discussed by chemists in the nineteenth century in Great Britain and France as a proxy for both nutritive and baking quality. It examines the way gluten featured in the broader quest to measure and render the quality of wheat and flour through a set of objective and quantifiable criteria. The paper also shows how measuring quality proved to be an extremely complex task, and how chemistry was, by itself, unable to reduce the complexity of the wheat grain, and the various demands made upon it, to a simple numerical indicator.
\end{abstract}

Gluten is in the limelight today. ${ }^{1}$ An increasing number of people avoid it because of its alleged role in causing celiac disease as well as many other food-related disorders. Estimates indicate that more than 3 million people in the US are now following a gluten-free diet. ${ }^{2}$ Meanwhile, many scientists

1 The authors wish to thank Christophe Bonneuil, Martin Bruegel, Laurent Herment, Ernst Langthaler as well as the two anonymous reviewers for their helpful comments upon earlier drafts.

2 Michael Specter, “Against the Grain: Should you go gluten-free”, The New Yorker, 27 October 2014; Niall McCarthy, “The Number Of Americans Going Gluten-Free Has Tripled Since 2009”, Forbes, 17 January 2017. 
and doctors counter that the prevalence of celiac disease is much exaggerated and that most of the gluten-free adepts are merely following a food fad, one with possible detrimental health effects. ${ }^{3}$ How different the situation was in the nineteenth century: gluten was also very often discussed but was almost always praised as "the whole life and soul of the bread", imparting strength to the bread but also to its consumer. ${ }^{4}$ The history of gluten in fact sheds interesting light on a wider discussion which took place in the nineteenth century and which had to do with the measurement of quality, and in particular the quality of the staple food of many European countries, i. e. wheat. This article thus places itself at the intersection of two historiographical trends. The first of these is the history of chemistry and nutrition science, which has shown how, from the late eighteenth century, many scientists discussed how to measure the nutritive quality of various food items, in a bid to make feeding more rational and efficient. ${ }^{5}$ The history of nutrition science is, like that of any other science, a story of controversies, competing claims and paradigms yet one trend is undeniable, the rise of quantification, and the article will show how gluten figured prominently in this trajectory. The second strand of investigation is that of the evolution of the wheat grain chain in the nineteenth century and, more precisely, the various attempts at formalizing quality. The seminal works of William Cronon and Aashish Velkar, in particular, have shown how the growth of a global wheat market required devising new metrological tools to facilitate inter-state and international transactions. ${ }^{6}$ What they have also shown is how these attempts at finding reliable selling and grading standards were often controversial, almost always context-dependent, and the quest to devise a set of objective, numerical and standardised set of "quality attributes” not realised before WWI at least. Yet, what is not entirely clear is how chemistry featured in these discussions. If, as Velkar has argued, "an increased understanding of the chemistry of wheat and advances in testing increased the sophistication of quality assessment techniques”, how exactly did chemistry intend to participate in the measurement of quality, and were its objectives fully realised? ${ }^{7}$ By looking at two countries in particular, France and Great Britain, the paper will show how gluten featured in discussions about the measurement of the nutritive and baking qualities of wheat and flour. It will study how chemists, in particular, promoted the quantification of gluten as an index of quality that could possibly be used in commercial transactions. The paper also shows, however, how the quest for an objective indicator proved more difficult than expected and how the attempt at reducing quality to one criterion proved unable to deal with the complexity of wheat and the various demands made upon it.

3 See for example Amy L. Jones, “The Gluten-Free Diet: Fad or Necessity?”, Diabetes Spectrum 30 (2017): 118-123, or Carolyn Newberry et. al., “Going Gluten Free: the History and Nutritional Implications of Today's Most Popular Diet”, Current Gastroenterology Report 19 (2017): 54.

4 "Gluten in Flour", The Miller, 7 November 1904: 498. Gluten in fact does not preexist as such in wheat or in flour, it is a protein network formed when flour is mixed with water but most discussions in the nineteenth century mentioned it as existing in wheat and flour so this article will adhere to the way it was conceived of at the time.

5 The history of nutrition science is attracting widespread interest at the moment but important works include Kenneth Carpenter, Protein and Energy: A Study of Changing Ideas in Nutrition (Cambridge: Cambridge University Press, 1994); Emma Spary, Feeding France: New Sciences of Food, 1760-1815 (Cambridge: Cambridge University Press, 2014); Corinna Treitel, Eating Nature in Modern Germany (Cambridge: Cambridge University Press, 2017); Elizabeth Neswald, Ulrike Thoms and David Smith, eds., Setting Nutritional Standards: Theory, Policies, Practices (Rochester: University of Rochester Press, 2017).

6 William Cronon, Nature's Metropolis: Chicago and the Great West (New York: Norton, 1991); Aashish Velkar, Markets and Measurements in Nineteenth Century Britain (Cambridge: Cambridge University Press, 2012), ch. 6 in particular.

7 Aashish Velkar, Markets and Measurements in Nineteenth Century Britain, 215. 


\section{Gluten : the true nutritive material?}

Gluten was first identified by the Italian chemist Jacopo Bartolomeo Beccari, who presented his findings in 1728 at the Bologna Institute. He showed how washing a dough in pure water left an insoluble glutinous residue, which was characteristic of wheat flour. Through his procedure, Beccari identified two basic substances contained in flour, the soluble "amylaceous" part (starch) and the insoluble, "glutinous", part (gluten). ${ }^{8}$ Beccari located the former substance within the "vegetal" realm and the latter within the "animal" one. What distinguished animal from vegetal substances was not their origin, but the way they decomposed: vegetable substances fermented while animal parts putrefied, just like meat. A few years later, in a doctoral dissertation presented at Strasburg in 1759, the physician Johannes Kesselmeyer argued that the glutinous matter of wheat was the "truly nourishing part of bread". ${ }^{9}$ If Beccari had merely emphasised the existence of two substances, one vegetal one animal, Kesselmeyer was in no doubt that it was gluten, the animal substance, which contained the "main nutritive qualities" of wheat and was the reason for its superiority over all other cereals. Gluten could be used as the way to quantify the quality of wheat, as the glutinous substance was to be found "in constant proportions for flours of the same quality" while "its quantity decreased if the wheat (was) of lower quality". ${ }^{10}$

As Emma Spary and Rebecca Earle have shown, food riots due to high bread prices in the second half of the eighteenth century prompted scientists to attempt to better understand what constituted “alimentary principles" and research on gluten stood at the forefront of the "Enlightenment's attempt to unravel the science of nutrition". ${ }^{11}$ The discovery of gluten in particular provided a new rational basis to explain the superiority of wheat compared to other staples, and the substance was endowed with various virtues. Tissot ascribed the "superiority" of wheat over all other types of grain to its large proportion of gluten. Other staples, such as maize or potatoes could produce muscular bodies, but only wheat and its nourishing principle, gluten, could make possible the intellectual prowesses produced by Europe. ${ }^{12}$ The presence of an "animal" substance contained in vegetal food vindicated the superiority of wheat which was seen as the perfect alliance of the animal and vegetable kingdoms, fit for omnivorous human. Consensus on the question was not complete, however, and some scholars argued that the focus of the "gluten extremists" on one substance was unduly restrictive, while others altogether dismissed the importance of gluten in nutrition. The most

8 Luca Borghi et al., "Storia della scoperta e dei primi studi sul glutine: Jacopo Bartolomeo Beccari (1682- 1766) et il saggio ‘De frumento””, La Rivista di Scienza dell’Alimentazione 46 (2017): 9-16.

9 Hervé This, "Who discovered the gluten and who discovered its production by lixiviation?”, Notes Académiques de l'Académie d'agriculture de France 3 (2018): 3-5.

10 Johannes Kesselmeyer, "Dissertatio inauguralis medica de Quorumdam vegetabilium Principio Nutriente" (Strasbourg, 1759), quoted in Ulysse Roy, Historique du gluten, découverte de ce produit alimentaire (Poitiers, 1862), 42-46.

11 Emma Spary, Feeding France; Rebecca Earle, "The Political Economy of Nutrition in the Eighteenth Century”, Past \& Present 242 (2019): 79-117.

12 M. Tissot, “Lettre à M. Hirzel, sur le blé et le pain” in Dissertation sur le blé et le pain, avec la réfutation de M. Tissot, M. Linguet (Neufchatel, 1779), 60. On the history of bread consumption in France see Steven L. Kaplan, Le meilleur pain du monde: les boulangers de Paris au XVIIIe siècle (Paris: Fayard, 1996) ; Steven L. Kaplan, Le retour du bon pain: une histoire contemporaine du pain, de ses techniques et de ses hommes (Paris: Perrin, 2002). On bread and wheat consumption in Britain see R. A. McCance \& E. M. Widdowson, Breads White and Brown (London: Pitman, 1956); E. J. T. Collins, "Dietary Change and Cereal Consumption in Britain in the Nineteenth Century”, The Agricultural History Review 23 (1975): 97-115 ; Christian Petersen, Bread and the British Economy (Aldershot: Scolar Press, 1995); David Fouser, "The Global Staff of Life: Wheat, Flour, and Bread in Britain, 18461914” (Phd, University of California, Irvine, 2016); Chris Otter, Diet for a Large Planet: Industrial Britain, Food Systems, and World Ecology (Chicago: Chicago University Press, 2020). 
famous opponent was the French chemist Parmentier who, in his quest to promote the use of the potato and of potato bread in particular, argued that the true nutritive substance was starch, not gluten. Yet Parmentier's downplaying of gluten was clearly opposed to "the mainstream of French alimentary chemistry" which, overall, maintained the superiority of gluten over other substances. ${ }^{13}$ Both in England and in France, the quantity of gluten came to be considered as the index of the nutritive qualities of bread. ${ }^{14}$ Even if they were rarely conclusive, gluten analyses were thus conducted to try and settle the controversial question of what type of bread (white, wholemeal, etc.) was the most nourishing: in 1800, for example, when a House of Commons Committee inquired into the question, the naval physician consulted considered that the quantification of "the glutinous matter" provided the most useful proxy to measure and rank the nutritional merits of different breads. $^{15}$

In the nineteenth century, gluten kept on being considered as the best proxy for both nutritional qualities. The French chemist Gay-Lussac for example declared in 1828 that of the two substances contained in wheat, gluten and starch, only the former, was "essential to nutrition": "Starch is much less nutritive than meat and could not be used for long as the sole source of nourishment, but as bread contains starch but also gluten, it is all the more nourishing as it contains more glutinous substances". ${ }^{16}$ In its 1841 report, the famous Gélatine Commission headed by Magendie, which fed dogs with various alimentary substances for three months, found gluten to be the only "alimentary substance" that could be taken in isolation without eventually resulting in ill-health or death: gluten was the only "immediate principle" that could "sustain life" and "nourish perfectly and for a long time". ${ }^{17}$ The period may even be said to have gone through a "gluten craze", as chemists and inventors tried to devise pure or concentrated gluten foods, such as Apollinaire Bouchardat's "gluten bread" (1841). ${ }^{18}$ Bouchardat's bread was especially recommended for people with diabetes, but the early 1850s witnessed other inventions of patent gluten foods that were meant to be consumed by everybody, such as the Veron brother's "granulated gluten” in France or “Bullock's semola” in Great Britain, which was branded as "the most nutritious substance ever used" ${ }^{19}$

Just like the late eighteenth century, the mid-nineteenth century was marked by an acute interest paid to questions of nutrition and the principles which could guide a more rational organization of the "animal economy". In the turbulent context of the 1840s, marked especially by rising concern and disturbances over food prices and availability, French and British chemists' efforts to devise an index of "nutritious quality" may thus be interpreted as an attempt to manage more rationally the inputs and outputs of all "living machines". ${ }^{20}$ Now, if gluten was considered as a "pure nutritive"

13 Emma Spary, Feeding France, 66-78.

14 See for example Samuel Parkes, A Chemical Catechism ( $2^{\text {nd }}$ ed., London: Lackington, 1807), 595.

15 Report Respecting Bread, Corn, 10 February 1800, House of Commons Parliamentary Papers, vol. 137, 37, quoted in Rebecca Earle, "Political Economy", on 112-113.

16 Joseph-Louis Gay-Lussac, “Cours de chimie. 31ème leçon, 25 juillet 1828”, in Cours de chimie, (Paris, 1828) vol. 2, 13-15 ; Antoine Peyrat, Du Gluten et de son Emploi (Paris : Faculté de Médecine, 1854).

17 Rapport fait à l'Académie des sciences, dans sa séance du lundi 2 août 1841, par M. Magendie, au nom de la Commission dite de la gélatine (Paris: Bachelier, 1841), 44 \& 47.

18 Apollinaire Bouchardat, "Sur un nouveau traitement du diabète sucré et sur l'emploi du pain de gluten dans cette maladie”, Bulletin Général de Thérapeutique Médicale et Chirurgicale 21 (1841): 341-347.

19 T. H. Barker, "Nursery Government in its Sanitary Aspects", Journal of Public Health and Sanitary Review 2 (1857): 370-371; Illustrated London News, 14 December 1850: 459.

20 Dana Simmons, Vital Minimum: Need, Science, and Politics in Modern France (Chicago: Chicago University Press, 2015), 15-30; “Rapport fait par M. Payen, au nom du comité des arts chimiques, sur la fabrication du gluten granulé établie par M.M. Véron frères”, Bulletin de la Société d'encouragement pour l'industrie nationale 44 (1845): 19. John Hannam, “On the Use and Application of Rape-Dust”, Journal of the Royal Agricultural Society of 
substance, it was because until late in the nineteenth century, nutrition science relied not on a thermodynamic paradigm (as the later, calorie-centered, "human motor" model would) but on the question of "flesh-forming" principles (proteins) measured in terms of inputs and outputs of nitrogenous substances, of which gluten was one. Starting in the 1840s, alimentary substances came indeed to be measured according to their contents in nitrogenous substances (the so-called plastic or "animal” substances) and non-nitrogenous substances (the respiratory or "vegetal” substances) yet only the former were considered as being really "nutritive", i. e. "flesh forming". Animal-cumvegetal nitrogenous substances like gluten stood at the intersection of the two realms and were thus fundamental in the "ceaseless routine" of nature and the "constant succession of animal and vegetable beings": they were the means by which seeds and plants could be transformed into "animal muscle". ${ }^{21}$

Gluten, in other words, was akin to vegetal meat. Some chemists even tried to quantify the "meatequivalent” of different types of bread. In 1853, Jules Reiset calculated the protein-intake of a French peasant consuming $9 \mathrm{~kg}$ of bread every week and found that the use of a wheat variety with a high nitrogen content, as compared with the use of a variety with a lower gluten content, was equivalent to an additional $1.715 \mathrm{~kg}$ of meat weekly. ${ }^{22} \mathrm{~A}$ few years later, Lailler, who was a pharmacist in a lunatic asylum, similarly attempted to illustrate the difference between various flours by quantifying their "meat-equivalence": elucidating the respective gluten and nitrogen contents of two types of flour, he argued that eating a kilogramme of bread made with the more glutinous one was akin to eating an additional 100 grammes of beef. ${ }^{23}$ Lailler went on to argue that there should be a legal minimum of gluten content, not only in hospitals, armies and institutions, but for private consumers as well; he suggested that public health inspectors should be charged with analyzing the flours in bakeries to check their gluten content, and that any flour which contained too low a quantity of "good gluten" should be prohibited. ${ }^{24}$

Given the importance attributed to gluten in the determination of nutritiousness and quality, it came to be regularly mentioned in debates about the respective merits of brown and white bread which developed in the second half of the nineteenth century, when advocates of wholewheat bread and opponents of modern milling methods often based their criticisms of white bread on its lower gluten and nitrogen content. ${ }^{25}$ In an 1868 pamphlet entitled The Bread of the People. Alimentary hygiene against degeneration, the author, a F. Arger, linked the alleged physical degeneracy of the French population with the spread of modern milling methods which, he argued, "broke” the gluten and

England 4 (1843): 179 (n. 1).

21 Anon., Wheat: its History, Characteristics, Chemical Composition, and Nutritive Properties (London: Houlston, 1865), $57 \& 61$.

22 Jules Reiset, “Mémoire sur la valeur des grains alimentaires”, Annales de chimie et de physique 39 (1853): 41.

23 A. Lailler, “Etude pratique sur le gluten et sur son dosage à l'état sec”, Annales d'hygiène publique, industrielle et sociale 46 (1876): 436.

24 Ulyse Roy, Historique du gluten, découverte de ce produit alimentaire. Deuxième partie: Panification du gluten (Poitiers, 1862), 1 ; Lailler, "Etude pratique sur le gluten”: 455.

25 J. P. Machet, Le Pain meilleur et à meilleur marché (Paris: Humbert, 1862);Antoine Balland, Recherches sur les blés, les farines et le pain (Paris: Charles- Lavauzelle, 1894) : 141. 
made it lose its "strength"26. In return, most chemists tended to defend white bread which, they argued, contained as much gluten as wholewheat bread and claimed that the proteins contained in the former were more easily assimilated. ${ }^{27}$ In the end, neither side could claim the superiority of their product by focusing on gluten alone, and the debate tended to move on to other elements such as phosphorus and "accessory food factors" (i. e. vitamins), but the point is that gluten figured rather prominently in these debates in the nineteenth century, illustrating how it was for long seen as the primary nutritive element in bread.

\section{Measuring quality}

If gluten was thus valued for its nutritional qualities, most chemists drew the conclusion that it could be used to assess and quantify the quality of wheat, and that this could and should be used in commercial transactions. Analyses of gluten started to be conducted to detect if flour had not in fact been eked out with inferior products or bran and to ascertain if flour had been properly stored. ${ }^{28}$ But more importantly, gluten tests could be performed to compare several kinds of flour and wheat. As early as 1807, the British chemist Humphry Davy performed wheat analyses in order to quantify the presence of gluten and starch in several kinds of wheat, and these analyses were read as providing some rough-and-ready guide to setting the cost of different types of wheat. ${ }^{29}$ In France, this type of analysis was commissioned by the army and by the administration in charge of Paris hospitals from the early 1820 s in order to rank several types of flour according to their nutritive value. ${ }^{30}$ In the 1840s and 1850s, this led to some attempts at quantifying the "real price" of "alimentary substances". ${ }^{31}$ One such theoretical attempt was made by the agronomist Gasparin who, using the average price and chemical content of the wheat and potatoes grown around Paris gave a relative price to nitrogenous and carbonaceous substances. He then argued that it was possible to set the relative price of any wheat based on the analysis of these alimentary substances. For example, if a sample of wheat contained $18.5 \%$ of nitrogenous and $81.5 \%$ of carbonaceous substances (compared with an average ratio of 14.3:85.7), its price should be 3\% higher than that of "normal wheat” sold in the Halles de Paris. ${ }^{32}$

But gluten was not just about nutritive quality and came to be increasingly valued for its rôle in baking quality as well. By the mid 1850s, it was clear that not only was high-gluten flour more nutritive than low-gluten one, but that "flours that are the most adapted to panification are those which contain a firmer, more elastic and more expansive type of gluten”. ${ }^{33}$ Gluten, in other words, was tightly associated with "strength": the strength which it imparted to the eater, but also the "strength" which it imparted to flour, i.e., its baking quality, its capacity to absorb water and to

26 F. Arger, Le Pain du Peuple: Hygiène Alimentaire contre la Dégénérescence (Paris : Arger,1868), 34.

27 "Rapport de M. Aimé Girard sur la valeur alimentaire des pains provenant de farines blutées à des taux d'extraction différents", Journal de la meunerie 157 (1896) : 13.

28 M. Henry, "Mélanges de farines de froment et de fécule de pomme de terre", Archives générales de médecine 7 (1829): 295. C. A. Briois, “Thèse sur le gluten et les mélanges de différentes farines” (Phd, Paris, 1856) ; Anselme Payen, "Mémoire sur différents blés et farines, expériences faites au Conservatoire national des Arts et Métiers", Bulletin des séances de la Société royale et centrale d'agriculture, 2nd. series 6 (1850): 425-26.

29 "Spring Wheat", The Lancaster Gazette and General Advertiser, 14 May 1808.

30 M. Henry, "Examen analytique de deux farines”, Journal de pharmacie et des sciences accessoires 8 (1822): 51-55; M. Vauquelin, “Analyse de diverses sortes de farines”, Journal de pharmacie et des sciences accessoires 8 (1822): 353-363.

31 Eugène Peligot, “Sur la composition du blé: Mémoire lu à l'Académie des Sciences, le 5 février 1849”, Annales de chimie et de physique 29 (1849): 3. 
produce a well-risen loaf. So it seemed natural to some that gluten should be considered in the setting of grain price, as proposed for example by the French chemist Jules Reiset. In 1853, Reiset, who ran a laboratory and a farm in Normandy and would become a député, argued that the current modes of giving a price to wheat, based on its density and visual aspect were in fact very imprecise and poorly appreciated the real qualities of wheat. According to Reiset, the only way to induce farmers to grow the best wheat was to take into account the quantity of gluten, and he gave the example of a wheat variety with $15.5 \%$ gluten which should fetch 25 frs for $100 \mathrm{kgs}$, while a variety with $9.54 \%$ gluten should be sold only $15 \mathrm{fr} 37 .^{34}$

There were indeed many reasons for wanting to find a way of quantitatively registering the quality (both nutritive and for bread-making purposes) of wheat in the second half of the nineteenth century. Until the mid-nineteenth century, wheat was sold on the basis of its natural weight, but transactions also depended very much on the tacit knowledge of millers who assessed commodities by visual and tactile inspection. ${ }^{35}$ Yet diminishing transportation costs and rising prices of domestic wheat in the 1850s had led to a wave of importations, especially from America, causing a great increase in the number of varieties, whose physical and nutritional properties were not always known. ${ }^{36}$ In France, Great Britain, and elsewhere, the mid-nineteenth century was thus marked by attempts to standardise the grading of wheat's quality to take into account its moisture, its density, its cleanliness, etc., although as we shall see, it proved impossible to devise an objective and "standardised set of attributes (...) to measure quality". ${ }^{37}$

The transformation of milling techniques also made it more difficult for bakers to assess the purity and quality of flour by touch alone. ${ }^{38}$ Traditionally, one of the main way for a baker to assess the quality of flour was to pass it “under his experienced fingers”. Yet, the development of new milling techniques, which produced a more uniform powder, rendered this method of testing less useful and accurate, thus creating the need for new methods and techniques of ascertaing end-quality attributes. ${ }^{39}$ Chemistry and gluten analyses also developed with the liberalisation of the trade which occurred in the 1850 s and 1860s. ${ }^{40}$ The clearest example of this is the creation of the "Paris-Type" of flour in 1863, one year after measures were taken to liberalise the baking trade. ${ }^{41}$ Before that, the

32 Gasparin's reasoning was as follows: the price of potatoes is $48 \%$ that of wheat. Given the ratio of nitrogenous and carbonaceous in these two items : (14.3/86.7 (sic) for wheat and 9.2 / 90.8 for potatoes), then $14.3 \mathrm{x}+86.7 \mathrm{y}=100$ $\& 9.2 \mathrm{x}+90.8 \mathrm{y}=48$, with $\mathrm{x}$ and $\mathrm{y}$ being the relative prices of nitrogenous and carbonaceous substances, so $\mathrm{x}=$ $3.52 \& y=0.466$, which could then be used to ascertain the relative price of all wheat and potatoes depending on their chemical composition. One notes here that Gasparin made a mistake in his wheat ratio (which should have been 14.3/85.7), but we are interested in his reasoning, not the actual figures he reached. Adrien Etienne Pierre de Gasparin, Cours d'agriculture, (Paris : Librairie Agricole, 1847), vol. 3, 632.

33 Antoine Peyrat, Du Gluten et de son emploi (Paris: Faculté de Médecine, 1854), 10.

34 Jules Reiset, "Mémoire sur la valeur des grains alimentaires”: 41.

35 Aahish Velkar, Markets and Measurements in Nineteenth Century Britain, 173.

36 Eugène Peligot, "Sur la composition du blé": 3 ; M. Ribot, "Note sur l'examen des farines et des pains", Annales de chimie et de physique 47 (1856): 50.

37 Aahish Velkar, Markets and Measurements in Nineteenth Century Britain, 187-192.

38 On transformations in the milling industry, see Richard Perren, "Structural Change and Market Growth in the Food Industry: Flour Milling in Britain, Europe, America, 1850-1914”, The Economic History Review, 2nd series 43 (1990): 420-437; Jennifer Tann and Glyn Jones, "Technology and Transformation: The Diffusion of the Roller Mill in the British Flour Milling Industry, 1870-1907”, Technology and Culture 37 (1996): 36-69; Glyn Jones, The Millers: A Story of Technological Endeavour and Industrial Success, 1870 - 2001 (Lancaster: Carnegie, 2001).

39 A. Boland, Traité Pratique de Boulangerie (Paris: Librairie Scientifique, Industrielle et Agricole, 1860 ), 174.

40 Judith A. Miller, Mastering the Market: The State and the Grain Trade in Northern France, 1700-1860 (Cambridge: Cambridge University Press, 2008), 295-300.

41 Jean-Augustin Barral, Le blé et le pain: liberté de la boulangerie (Paris, 1863). 
four largest millers in Paris sold as " 4 brands" their flour or any flour that they vouched for, and the quality of the products was guaranteed by the "honorability" of their names. ${ }^{42}$ Yet, this method was judged unable to assess the quantities of flour that were handled in a market increasingly dependent upon speculation and futures-trading. The creation of the "Paris-type" brand allowed millers around Paris to sell their product as "Paris Type", as long as they conformed to a quality standard. There were several criteria whereby the Commission formalised on a monthly basis the flours seeking certification, but one of the most important one was the quantification of gluten: in order to be accepted as a Paris-type brand, a given flour needed to contain as much gluten as the average of the other brands. With this type of measure, it was hoped the milling trade would be able to develop quality certification techniques that did not depend solely upon the reputation of a given miller, but could be made quantifiable and impersonal. ${ }^{43}$ Not only was the average gluten content of the "Paris Type” and of the leading Paris brands published on a monthly basis in baking and milling journals, but bakers were routinely advised on the procedures which they could follow in order to measure as precisely as possible the gluten content of a flour. If unsure, bakers could have their flours checked at pharmacists or analysts who would perform gluten analyses. ${ }^{44}$ Given the added cost of these analyses and the "luxury" type of flour involved in these transactions, it seems that gluten analyses were primarily reserved for the more expensive "white" products, but it must be noted that by the late $19^{\text {th }}$ century, the white loaf had become almost ubiquitous in Britain, and large cities in France, Paris in particular, were following the same trend. ${ }^{45}$

Yet, if consumer's tastes appeared to be increasingly homogenous, this was not the case of the raw material used to manufacture flour and what chemical analysis promised was a way to numerically formalise quality in an ever more complex market, where "the differences in qualities between varieties as well as the consistency of quality in a given variety became crucially important”, ${ }^{46}$ Scientists thus argued for the importation of their methods in the assessment of the quality of wheat and flour since "the miller is constantly dealing with a very variable type of raw material. Not only does the quality of wheat vary each year, but also depending upon the place in which it was grown, the time of year in which it was harvested, the care with which it has been stored, etc. and with this ever-changing quality grain, the miller must produce flour which needs to be standardised in composition, granulation, colour, etc. in order to have commercial value. [...]". ${ }^{47}$ Chemists thus attempted to assert the usefulness of their expertise in a situtation where raw material was increasingly heterogenous while industrial processes and consumer tastes required more predictability and homogeneity. The push of chemists for gluten analyses must also be seen in the wider context of the second half of the 19th century when, as Carolyn Cobbold and Benjamin Cohen have recently shown, rising concerns with adulteration and the use of new chemical additives and processes prompted calls for more stringent food safety controls, and the rise of a new regulatory regime in which food chemists strove to play a central rôle. ${ }^{48}$

42 A. Tailleur, Commerce des céréales: Type-Paris pour les farines, étude extraite du journal l'Echo agricole (Paris : Guillaumin, 1864), 6.

43 A. Cochut, "Le Pain à Paris”, Revue des Deux Mondes 47 (1863): 400-435 : see also Alessandro Stanziani, “Accaparement et spéculation sur les denrées alimentaires: au-delà de la pénurie”, in Profusion et pénurie: Les hommes face à leurs besoins alimentaires, ed. Martin Bruegel (Rennes: Presses Universitaires de Rennes, 2009), 103-120.

44 See for example "Classement des Farines Huit-Marques”, Annuaire de la boulangerie de Paris (Paris, 1882 ): 32.

45 John Burnett, Plenty and Want (Harmondsworth: Penguin, 1968), on 16 \& 139-40; E. J. T. Collins, "Dietary Change and Cereal Consumption in Britain in the Nineteenth Century”, The Agricultural History Review 23 (1975): 97-115.

46 Aahish Velkar, Markets and Measurements in Nineteenth Century Britain, 199.

47 Georges Petit, "Les laboratoires d'essai des farines”, Journal de la meunerie 161 (1896): 90.

48 Benjamin R. Cohen, Pure Adulteration: Cheating on Nature in the Age of Manufactured Food (Chicago: Chicago University Press, 2019); Carolyn Cobbold, A Rainbow Palate: How Chemical Dyes Changed the West's 


\section{Basing sales on assay?}

So, it seemed to some that the time was now ripe for sales "on chemical assay”. One M. GuérardDeslauriers, a civil engineer and member of Caen's Chamber of Commerce argued that in the mercuriales of grain markets, the gluten content of all wheat sold should be indicated, so that bakers could check the quality of the flours that they bought. As Lailler, the pharmacist mentionned earlier, argued: "we may soon reach the stage where, thanks to progress in education and the spread of science, the cultivator will be able to state that the wheat he is selling contains so much gluten, or the miller will be able to say the same thing to the baker, who will find that it is in his interest to know the proportion of this principle in the flour which he is offered". ${ }^{49}$

Even in the laboratories of Paris or Rouen, the prime mode of measuring and ascertaining quality remained based on actual bread-making, yet this procedure, according to Lailler and others, afforded no indication as to the nutritive qualities of bread, which could only be measured by their nitrogen content. ${ }^{50}$ Describing the traditional methods used by millers and bakers to ascertain the quality of wheat and flour as "of the crudest description", chemists argued that only a proper analysis could guarantee the quality of the product, and ensure that results would be accurate, standardised, consistent, and reflected its nutritional value. Moreover, chemical analysis would make long-distance sales on sample and futures trading more convenient, since bread-making tests remained burdensome and difficult and could afford no guarantee as to the consistency of the flour's or wheat's qualities. A precise numerical value ascribed to quality was indeed the only guarantee in case of arbitration after futures sales or sales on samples. In Great Britain, the chemist William Jago argued that the various classifications that existed in Britain for the selling of flour (town superfines, town whites, town households, etc.) were not fit for an age marked by a widening array of wheat varieties and flour type: “a better and more trustworthy classification” had now become necessary, he argued, and he hoped that baking tests would ultimately be replaced by "strength tests" which would ascribe a numerical value to the bread-making and nutritive qualities of a given flour. ${ }^{51}$

The model here was clearly the evolutions that the trade in fertilisers had undergone since the 1860s. Discontent with the frequent adulteration and varying quality of fertilisers had led some manufacturers to indicate the nutrient (NPK) content of the fertilisers that they sold, a custom that eventually became compulsory in 1888 in France and 1893 in Great Britain. For proponents of sales by analysis, this type of guarantee should be extended to the sale of wheat and flour, as a compulsory indication. ${ }^{52}$ As Jago put it :

"The fact that manures and artificial cattle foods are continually bought and sold by analysis, shows that the principle is one which is capable of being worked commercially. Custom is undoubtedly the chief obstacle to its being successfully adopted in the corn and flour trade. In the

Relationship with Food (Chicago: Chicago University Press, 2020).

49 “Rapport de M. Guérard-Deslauriers”, in Rapports du comité départemental du Calvados sur l'exposition universelle de 1867 à Paris (Caen, 1869), 240.

50 A. Lailler, "Etude pratique sur le gluten”: 449.

51 William Jago, “Modern Developments of Bread Making”, Journal of the Royal Society of Arts 38 (1890): 85.

52 On the influence of the fertiliser market, see for example "Rapport de M. Guérard-Deslauriers", 241. On chemists and fertilisers see Nathalie Jas, Au carrefour de la chimie et de l'agriculture: Les sciences agronomiques en France et en Allemagne, 1840-1914 (Paris: Archives contemporaines, 2001). 
open market, corn buying and selling is done from sample, and provided the bulk of the parcel tallies in appearance and general outward characteristics with the sample on which purchase is effected, the miller must trust entirely to his own judgment as to quality and yield of flour; it is well known that the opinion formed under these circumstances cannot be uniformly depended on. (...) Supposing a system of commercial assay of wheat to be adopted for buying and selling purposes, the corn merchant would offer his samples under guarantee that their strength, gluten, etc., were so much, giving the results of assays he has had made on his behalf. In case of the buyer finding the bulk of the wheat not coming up to the seller's guarantee, he could as now refer the matter to arbitration; the only difference would be that a chemist would have a seat on the board of arbitrators, and would certify as to the respective merits of the samples in dispute, when subjected to a commercial assay". ${ }^{3}$

As the previous quote indicates, Jago and other flour chemists were trying to promote their expertise for commercial transactions and arbitration. In his proposal for "commercial assay" Jago was also hoping to benefit from the increasing interest of millers in science and technology, as developed in new reviews (Milling, Miller), and technical courses developing in the 1880s. In 1884, he had tried to launch a new publication called A Confidential Report on the Wheat and Flour Supply. This report, which contained numerous chemical analyses of English and foreign wheats (in its first year, Jago performed and published the results of 181 analyses), was reserved to subscribers who were also entitled to personalised advice and, more importantly, discount rates on wheat and flour analyses. Theoretically, millers could use Jago's Confidential Report to compare the gluten and albuminoid proportions of various sorts of wheat to help them buy wheat at the right price, and Jago's objective was "to place the result of chemical investigation of problems that are of importance to the milling and bread-making crafts within reach of every miller and baker”, by acculturating them to the notions that he felt were indispensable to the assessment of wheat quality. ${ }^{54}$ Yet Jago's hope was disappointed. Even by offering subscribers gratis tests, the publication never reached his objective of a thousand subscriptions and publication was discontinued in 1886. Jago nevertheless continued to press the value of chemistry in determining bread and flour quality, by devising and selling various instruments for flour testing, setting up a laboratory and publishing widely on wheat and flour chemistry. ${ }^{55}$ In France as well, analytical science undoubtedly made some progress, as seen for example in the creation of the Laboratoire du syndicat de la boulangerie de Paris in 1892, which performed gluten and other analyses for free. Yet, as Lindet deplored, "no matter how beautiful and practical a laboratory is, it takes a long time before people learn how to require its services: they need to be shown the services that the lab can perform and learn by themselves how profitable it is to them". ${ }^{56}$ The emphasis on gluten and chemical analysis was thus part of a wider attempt by chemists to secure a more important role in the control over grain and flour transactions, yet it appears that many millers and bakers preferred to rely on their own tacit knowledge rather than on the chemists' formal procedures. ${ }^{57}$

53 William Jago, The Chemistry of Wheat (Brighton: Jago, 1886), 379. Jago asserted that he could perform the test in under 4 hours.

54 William Jago, A Confidential Report on the Wheat and Flour Supply of the United Kingdom. For the use of Millers, Bakers and Cornfactors, (Brighton: Jago, 1885) vol. 5, 4.

55 William Jago, A Text-book of the Science and Art of Breadmaking, including the Chemistry and Analytical and Practical Testing of Wheat, Flour, and other Materials used in Baking (Brighton: Jago, 1895).

56 Léon Lindet, "Rapport présenté par M. Lindet, au nom du Comité d’Agriculture, sur le service scientifique du syndicat de la boulangerie de Paris”, Bulletin de la Société d'encouragement pour l'industrie nationale 103 (1904): 270-272. 


\section{Dealing with complexity}

In their bid to insist on the relevance of their expertise, most chemists argued that the crude separation of gluten with water, which could be performed by almost anyone, was in fact not a trustworthy method. For example, it was found that the gluten content of flours varied considerably according to the hydration of the gluten, the length of time that passed between the preparation of the dough and the extraction of the gluten, the type and the temperature of the water used, etc. ${ }^{58}$ It could therefore, chemists argued, not be reliably used, especially when there were judicial contestations. ${ }^{59}$ As early as 1837 , Boussingault had used a new method to measure the quantity of gluten in flours made from twenty five types of wheat, and rather than rely on the crude measurement of the gluten obtained by washing, Boussingault set to devise a formula which could be used to deduct the quantity of gluten from the total quantity of nitrogen contained in a flour, a procedure which was allegedly more precise but which could only be performed by chemists. ${ }^{60}$ Boussingault's work was followed by a string of related analyses which measured the gluten and nitrogen content of wheat. Chemists pressed the point that only through a careful dosage performed by a professional chemist or pharmacist could the quality of a wheat or flour be ascertained with precision and certainty. Yet, this type of analysis remained rather impractical for buyers and in the end it was mostly the "wet gluten "method that continued to be used unless very specific circumstances required a proper chemical analysis. ${ }^{61}$

If one finds repeated examples of arguments in favour of sales by gluten until at least the early twentieth century, it seems indeed that this horizon kept receding and never fully materialised. As chemists frequently deplored, millers continued to judge the quality of wheat by its density and by empirical sensory analysis. It was in fact widely recognised that gluten content was only one among many of the qualities looked for in wheat and flour. Already in the 1850s, Louis Edouard Rivot, from the Ecole Impériale des Mines, had written that if gluten tests could allow to rank quality, chemical analysis could only go so far: "chemical analysis is unable, on its own, to assess the quality of flour or of bread, as the various mixes which have been performed to manufacture flour, and its physical condition are of much more bearing to the quality of bread than its chemical composition". ${ }^{62}$ And a whole set of other testing apparatus were invented in the second half of the nineteenth century to register numerically other qualities, like tests to, for example, objectivise the colour of flour, such as Pekar's method or the tintometer, which, however, still relied very much on the judgement of the person using it. ${ }^{63}$

57 On the rise of food chemistry, see Pierre-Antoine Dessaux, "Chemical Expertise and Food Market Regulation in Belle-Epoque France”, History and Technology 23 (2007): 351-368; Uwe Spiekermann, “Redefining Food: The Standardization of Products and production in Europe and the United States, 1880-1914", History and Technology 27 (2011): 11-36.

58 Balland, Recherches sur les blés, 68 ; Charles Manget, “Contribution à l'étude de la chimie industrielle des farines et particulièrement du gluten et de l'acidité” (Phd., Nancy, 1901).

59 William Jago, A Text-book of the Science and Art of Breadmaking, 513-514.

60 Jean-Baptiste Boussingault, "Mémoire sur la quantité de gluten contenu dans les farines de plusieurs espèces de fromens cultivés dans le même sol”, Annales de chimie et de physique 65 (1837): 301-320.

61 Eugène Peligot, “Sur la composition du blé: Mémoire lu à l'Académie des Sciences, le 5 février 1849”, Annales de chimie et de physique 29 (1849): 3 ; Antoine Balland, Recherches sur les blés, 168.

62 Louis Edouard Rivot, "Note sur l'examen des farines et des pains”, Annales de chimie et de physique, 3rd series 47 (1856): 56.

63 “Essais des farines”, Journal de la Meunerie 122 (1893): 18-9 
Concerning gluten, it became clearer and clearer that the mere weighing of gluten was an unreliable and inconsistent method. It became increasingly obvious that the quantity of gluten was too crude an indicator of quality, as what mattered most was the "condition" of this gluten. ${ }^{64}$ Firstly, poor milling or storing methods could alter the elasticity of gluten, which could therefore not be measured by quantitative analysis alone. ${ }^{65}$ More importantly, the wheats with the highest gluten content were not necessarily those that produced the "strongest" flours. Very hard wheats for example contained a lot of gluten but had a poor "dilatation power" and could not be used to bake the highly aerated breads that urban populations, in particular, preferred. ${ }^{66}$ The idea that the quantity of gluten in flour could be a reliable indicator of its quality thus came increasingly under attack in the later years of the nineteenth century: "theory and practice have proven that it is impossible to reach precise and stable figures, so it is high time to abandon this archaic method". ${ }^{67}$

There were thus "considerable difficulties" that forced chemists to find new ways, beyond mere chemical analysis, to quantify the strength of wheat, and most analysts resorted to a physical analysis in their attempt to find a numerical index of quality. The most widely spread instrument for measuring the quality (and not the quantity) of gluten was Boland's aleurometer which attempted to measure the "power of expansion" of various glutens. ${ }^{68}$ Yet it was widely acknowledged that the results by Boland's aleurometer provided only indicative information and afforded no proper guarantee as to the quality of a given flour. The results varied enormously depending on whether the gluten used was dry or humid, whether some air had been allowed to get into the instrument, or on the amount of heat used, so that it came to be increasingly seen as untrustworthy and it went out of favor by the end of the century. ${ }^{69}$ Other instruments developed in the last two decades if the nineteenth century included William Jago's "strength burette" (to measure the water-absorbing capacity of flour), the "viscometer" (to estimate the consistency and stiffness of a dough), and Kunis' "farinometer", which were all variations of Boland's aleurometer and measured the expansion of gluten or of a dough subjected to heat. ${ }^{70}$

Despite the creation of these new (physical, not chemical) instruments, sensory analysis remained the prime method of ascertaining quality. If the "wet gluten" method was favored, it was not only because it was more practical but because it left room for a more personal and sensory approach to quality. What mattered most, even to many chemists, was not so much the quantity of the gluten as its "feel and appearance". ${ }^{71}$ In the end, the ultimate test for bread-making quality was still to ... bake bread. As a milling textbook from the 1900s put it : "the only safe way to ascertain the quality of flour from an unknown wheat would be to ... have the flour baked", while the other methods of testing flour quality, such as gluten tests, were judged "misleading”. ${ }^{22}$ In the late nineteenth century,

64 J. B. Lawes and J. H. Gilbert, On Some Points in the Composition of Wheat Grain, its Products in the Mill and Bread (London: Harrison, 1857): 51.

65 Louis Edouard Rivot, "Note sur l'examen des farines et des pains": 58.

66 Anselme Payen, "Mémoire sur différents blés”: 421-424.

67 G. Rechtsamer, "La quantité de gluten contenue dans la farine et la qualité de cette dernière à la panification”, Journal de la meunerie 122 (1893): 24-25.

68 A. Boland, Traité pratique de boulangerie (Paris: Librairie Scientifique, Industrielle et Agricole, 1860), 180.

69 Aimé Girard, “Analyse chimique et microscopique des principaux produits de mouture, fournis par les essais exécutes sous la surveillance de la commission spéciale nommée par la chambre syndicale des grains et farines de Paris (1883-84)", Bulletin de la Société d'encouragement pour l'industrie nationale 84 (1885): 140.

70 William Jago, The Chemistry of Wheat, 383-391 ; “Appareil Porther pour l'essai des farines”, Journal de la meunerie 116 (1893): 135-7.

71 William Jago, A Text-book of the Science and Art of Breadmaking (Brighton, Jago, 1895), 513.

72 William Halliwell, The Technics of Flour Milling: A Handbook for Millers (London: Straker, 1904), 262. 
the Paris-Type Commission, for example, continued to perform gluten content analyses but it was clear that the main criteria for ranking and certifying flours as "Paris-Type", were colour and a proper baking test. ${ }^{73}$

\section{The elusive quest to formalise quality}

Despite these difficulties, the need for quantitative indicators of quality remained paramount, in an increasingly global trade. At the turn of the twentieth century, Europe was faced with rising quantities of wheat imported from the US but some complained that the American system of grading, through elevator certificates, was untrustworthy and afforded buyers in Europe few guarantees. Since certification was practiced in the US and was final, these sales on certificates afforded no room for contestation or compensation claims if the quality of the delivered product did not correspond to what had been promised. ${ }^{74}$ The US system of classification was, in particular, reproached with being too crude, having too few nuances of quality, depending overly on the judgement of inspectors, and as affording very little precise information on the strength of the wheats bought. ${ }^{75}$ But the search for a reliable indicator of quality was just as necessary for domestic wheats. In both Britain and France, millers had allegedly acquired a "prejudice” against homegrown wheats and felt that it was necessary to mix the weaker domestic flours with stronger American or Russian wheats, that phenomenon being particularly important in Britain where $80 \%$ of the wheat milled was imported in the 1900 s. $^{76}$

Millers had actually incorporated the question of gluten in their lexicon of end-quality attributes, and milling handbooks routinely described some (English) wheats as "being weak or deficient in the gluten department" or on the contrary other (Russian in this case) varieties as being in great demand because of their "glutinous properties". ${ }^{77}$ Yet the varying "glutinous" characteristics of wheat varieties were mentioned as general properties that characterised certain types of wheat (American, Russian) rather than as a numerical index (no figures were given). Millers, in other words, had appropriated the lexicon of chemistry without necessarily relying upon its analyses and were generally not ready to let another craft (chemists) have the final word on quality. In any case, the result was that millers were now increasingly seen as being "prejudiced” against domestic varieties. In England for example, before the rise of imports, there had been a wider price differential between the stronger and the weaker domestic wheats. But since the arrival of strong US wheats, that strength "premium" had disappeared leading the older stronger domestic varieties (Red Lamma, Rough Chaff) to go out of use as farmers tried to counter ever falling prices by higher yields. In

73 Aimé Girard, "Rapport sur l’organisation, par M. C. Lucas, du laboratoire d’expertises de la commission des farines douze-marques”, Bulletin de la Société d'encouragement pour l'industrie nationale 85 (1886): 281-284 ; Charles Lucas, "Des expertises du marché des farines neuf-marques”, Bulletin de la Société d'encouragement pour l'industrie nationale 85 (1886): 284-291.

74 “General Meeting of the National Association of British and Irish Millers, 9 December 1903”, The Miller, 4 January 1904: 663-64.

75 G. Rechtsamer, “La quantité de gluten contenue dans la farine et la qualité de cette dernière à la panification”, Journal de la meunerie 122 (1893): 24-25 ; Aashish Velkar, Markets and Measurements in Nineteenth Century Britain, 190.

76 Chris Otter, Diet for a Large Planet, 48-55.

77 William Halliwell, The Technics of Flour Milling, 221. 
1902 the best English wheat was worth no more than 28s 6d per quarter, while Russian wheats and Hard Manitoba commanded respective prices of 33s and 35s. ${ }^{78}$

In both countries, a "gluten crisis" was widely lamented at the turn of the twentieth century: it was for example frequently commented upon that the flours sold in Paris had seen their average dry gluten content drop from $10.10 \%$ in 1871 to $7.80 \%$ in 1893 and $6.5 \%$ in $1904 .^{79}$ In both Britain and France this decrease in gluten content and quality was ascribed to the rapid spread of the new, mostly English, high-yielding varieties that were more responsive to increased use of fertilisers (Stand Up, Goldendrop, Victoria), which had a very poor "industrial value", as the bread-making qualities of wheat came to be called. For a long time in the nineteenth century, as quality was ascribed to its content in nitrogenous material, it had been relatively natural to assume that a wheat grown with liberal additions of nitrogenous fertilisers would give a nitrogen-rich and high-quality wheat. As one author put it in the 1860s: "It is evident therefore, if gluten is an essential part of good wheat, that nitrogen, which is the basis of gluten, is equally necessary to its production. Wherever, in fact, nitrogen is present in abundance in a soil, the wheat grown upon it is found to abound in gluten in an equal proportion”. ${ }^{80}$ By the 1900s, however, it had become clear that it was not possible to draw any link between the use of nitrogenous fertilisers and gluten-content. If anything, the quality of wheat seemed to be decreasing when fertilisation increased: baking tests performed upon wheats grown in British experimental stations and which had received the largest amounts of fertilisers were found to be "not even good enough to bake". ${ }^{81}$

For some like Fleurent, the solution was to abandon the new varieties and go back to the traditional varieties with lower yields but a higher gluten content. For others, the only solution was to breed new, stronger varieties while maintaining high yields. This was especially the case of the work jointly pursued by Gatellier, L'Hôte and Schribaux, a chemist, a wheat breeder and a miller / farmer, who tried to develop high-gluten wheats. ${ }^{82}$ In any case, whether the solution was returning to the older varieties or breeding new, stronger ones, there was a need to formalise what "strength" meant, in order to provide buyers with objective information on quality so as to override their "prejudices" against domestic varieties. ${ }^{83}$ Gluten analyses could thus play a rôle in creating a premium on quality and thus give farmers an incentive to grow stronger wheats, which would fetch a higher price and compensate for their lower yields. This explains why, despite the shortcomings of gluten content as an indicator of quality, some like the milling chemist Remilly, still entertained the idea of selling wheat by its gluten content: “There will probably come a time when the milling industry, like other agricultural industries, will base its purchases on the proportion of useful substances contained in raw material, which means gluten in this case". ${ }^{84}$

78 A. D. Hall, “The Question of Quality in Wheat”, Journal of the Board of Agriculture 11 (1904): 323-337.

79 Emile Fleurent, "Relation entre la proportion de gluten contenue dans les blés et la proportion de matières azotées totales", Journal d'agriculture pratique 68 (1904): 41-43. On the "gluten crisis” see also "Le gluten et les farines françaises”, Journal de la meunerie 211 (1901): 122.

80 Anon., "Wheat: its History, Characteristics, etc.": 61.

81 A.D . Hall, “The Quality of English Wheat”, The Miller, 1 August 1904: 312.

82 Emile Gatellier, H. L’Hote, Emile Schribaux, Etudes sur le Blé. 1. Richesse en Gluten 2. Création de nouvelles variétés (Meaux: Charrioux 1889); Emile Gatellier, "La culture du blé”, Mémoires publiés par la Société centrale d'agriculture de France 133 (1889): 579-606 ; MM. Gatellier \& Schribaux, "De la nécessité d’augmenter la qualité des blés indigènes français”, Bulletin des séances de la Société nationale d'agriculture de France 54 (1894): 604612.

83 Henri Hitier, “Notes d'agriculture”, Bulletin de la Société d'encouragement pour l'industrie nationale 108 (1909): 177-184. 
For breeding purposes as well, it was deemed important to find a ready-made "laboratory measure" of strength, which could be used as a preliminary test to discriminate quickly between a large set of varieties. ${ }^{85}$ Chemists in France, Great Britain and elsewehere were thus still actively trying to find an indicator that was more reliable and precise than gluten content. In France, Girard and Fleurent, under instructions from the French Ministry of Agriculture, started in 1896 to analyse 200 varieties of wheat to find out a chemical means of numerically registering their quality. After the death of Girard in 1898, Fleurent continued the analyses on his own and arrived at the conclusion that what mattered was not the quantity of the gluten but its composition. As early as 1819, Taddéi had identified two different substances in gluten, one that was soluble in alcohol (gliadin) and another insoluble substance (which he called zimome). ${ }^{86}$ Girard and Fleurent determined that the optimal ratio was $75 \%$ gliadin / $25 \%$ glutinen (the name that they gave to the insoluble substance) ${ }^{87}$ One commentator of Girard and Fleurent's work hoped that, at last, chemistry had found a means to measure grain quality: these results would enable both millers and breeders to know precisely "the real value, the baking value, of a given variety of wheat". ${ }^{88}$ With this new metric, the entire grain chain could at last be based upon scientific principles, and quality be made more predictable and dependable: not only could breeders and farmers select varieties with a known quality-index, but this would also help millers make "rational mixes" : knowing the glutenin / gliadin ratio of various wheats, millers could now "obtain milling products with a standardised quality" and "correct defective flours" "by adjusting the glutenin / gliadin ratio and by increasing the quantity of nitrogenous substances”. ${ }^{89}$ Fleurent and Girard's work was replicated by Snyder in the US and Guthrie in Australia but the figures that these scientists arrived at differed in a rather significant way, and reception of this new discovery was lukewarm at best, especially in Great Britain. In The Miller, for example, a reader exclaimed: "It seems to me not at all necessary that the manufacturer of flour, so far as his business is concerned, should trouble himself much about the difference between gliadin and glutinen". ${ }^{90}$ A. D. Hall (of Rothamsted) dismissed Fleurent's theory altogether, arguing "no particular ratio (could) be selected as more indicative of a good gluten than any other". 91

If Hall was interested in Fleurent's work, it was because in Great Britain as well, scientists were also looking for a way to define "what makes strength from the chemist's point of view" as a preliminary step towards breeding new, stronger domestic varieties to diminish Britain's dependence on foreign wheat imports. ${ }^{92}$ In the early years of the twentieth century, the question of strength remained as difficult as ever to define with precision: was it primarily about the quantity of water that a sack of flour could absorb? Could it be defined by the number of loaves produced with

84 Société d'agriculture et des arts de Seine-et-Oise, Congrès de la vente du blé. Versailles, 28, 29 et 30 juin 1900 (Versailles: Aubert, 1901), 79.

85 A. D. Hall, "The question of quality in wheat".

86 “Extrait du rapport fait à l’Académie Royale de médecine sur le Gluten-Granulé de MM. Veron”, in Ulysse Roy, Historique du gluten, 58; see also G. G. Nasmith, The Chemistry of Wheat Gluten (Toronto: University Library, 1903).

87 Aimé Girard, "Recherches sur la composition des blés et sur leur analyse”, Bulletin de la Société d'encouragement pour l'industrie nationale 96 (1897): 691-699 ; Emile Fleurent, Notice sur la détermination de la valeur boulangère des farines de blé tendre au moyen d'un appareil dit gliadimètre (Paris, 1900).

88 Georges Petit, “Analyse et composition des blés”, Journal de la meunerie 167 (1897): 214.

89 “La répartition du gluten”, Journal de la meunerie 180 (1898): 228-229; “Composition élémentaire du gluten”, Journal de la meunerie 187 (1899): 128-131.

90 “Scientific Flour Milling”, The Miller, 5 September 1904: 372.

91 A. D. Hall, "The question of quality in wheat”: 329.

92 "Council Meeting of the National Association of British and Irish Millers”, The Miller, 2 May 1904: 141 
a given quantity of flour? Or was it about the consistency, toughness and elasticity of the end product? ${ }^{93}$ When, concerned about the dependence of Great Britain on foreign wheats, the Royal Commission on the Supply of Food and Raw Materials in Time of War (1903-05) enquired into the way that experts defined and measured "strength", none of them could give a straightforward answer. Robert Henry Rew, an agricultural statistician from the Board of Agriculture and Inspector of Corn Returns at Mark Lane, candidly confessed that he could not define what he meant by "strength" ${ }^{94}$ So when the National Association of British and Irish Millers set up a committee on the improvement of English wheat, the latter adopted a rather vague and qualitative definition that did not really lend itself to scientific formalisation: "a strong wheat is one which yields flour capable of making large, well-piled loaves". ${ }^{95}$ And in their laboratory work to test the strength of various wheats, the committee did not use any of the instruments or procedures mentioned above, but relied instead upon a "practical baker" who performed baking tests and allotted "marks to them on an arbitrary scale representing his own judgement”. ${ }^{96}$

More importantly, the Committee found no satisfactory way of linking gluten and strength. When English wheats were tested, one of the worst rated wheat had the highest gluten content, and the wheat that got the second best baker's mark, for example, had an average gluten content and its gliadin content was unexceptional as well. So all methods were discarded by the British Committee except for the "estimation of the total nitrogen percentage" which afforded some rough indication of strength for wheats grown in the same conditions but should be taken with considerable caution, since it was "by no means an absolute measure of strength". ${ }^{97}$ As the milling press put it rather despondently: "the gluten theory is discarded and we are plunged once more into an acute controversy (...), we are left entirely without a theory of any description. There is no scientific explanation of any consequence as to what does or does not constitute the element of strength in wheat". ${ }^{98}$ In France as well, Vilmorin and other breeders came to the same conclusion thatneither flour's "nitrogenous content, nor its gluten content nor the composition of its gluten" were useful measures of its quality. ${ }^{99}$ Finally, the nutritional supremacy of gluten was dealt a heavy blow in the 1900s as nutrition science shifted its focus away from "nitrogenous substances" (proteins) to focus rather more on carbohydrates and calories, and what was known at the time as "accessory factors", later to be called vitamins. ${ }^{100}$ As Fleurent himself put it in 1909, it was not useful, from a nutritional point of view to try and grow wheats that were too rich in gluten, since this would be at the expense of carbohydrates. $^{101}$

93 A. E. Humpfries \& R. H. Biffen, "The Improvement of English Wheat”, Journal of Agricultural Science 2 (1907): $1-16$.

94 Report of the Royal Commission on the Supply of Food and Raw Materials in Time of War, Vol. II, Minutes of Evidence (London: HMSO, 1905), 362.

95 A. E. Humpfries \& R. H. Biffen, "The Improvement of English Wheat": 4.

96 A. D. Hall, "The Question of Quality in Wheat": 326.

97 A. E. Humpfries \& R. H. Biffen, "The Improvement of English Wheat": 5.

98 “The Gluten Theory”, The Miller, 6 June 1904: 181.

99 "La valeur boulangère des farines", Gazette agricole, 22 December 1907: 805.

100 F. G. Hopkins, a Reader in Chemical Physiology at Cambridge, was conducting research on the nutritional importance of unknown "accessory food factors" before WWI while the Polish Casimir Funk coined the expression "vitamines" (the final -e was later dropped) in 1912. See Kenneth J. Carpenter, "A Short History of Nutritional Science: Part 3 (1912-1944)”, The Journal of Nutrition 133 (2003): 3023-3032.

101 Emile Fleurent, "La fonction alimentaire du pain et le problème agricole et industriel de l'enrichissement des blés en matière azotée”, La Meunerie française 25 (1909): 296-300. 


\section{Conclusion}

From the beginning of the nineteenth century, chemists sought, for political, professional and commercial reasons, to find a unit that could reduce the complexity of the quality of wheat to a criteria that could be objective and numerical. To formalise quality, they thus attempted to measure the quantity and the quality of gluten, often perceived as being a key proxy to quality, due to its nutritional and physical properties. At the turn of the twentieth century, that objective had only been very partially fulfilled. If it proved easy to extract gluten and to use it as an indicator of quality in commercial transactions, the quantification of gluten proved unable - on its own - to estimate and anticipate the baking properties of a given sample of flour. Flour chemistry did of course become institutionalised and gained importance partly thanks to this work but it did not prove possible to reach an easy consensus as to what should be taken as the prime indicator of quality: reducing the materiality of the grain to a set of figures proved a more difficult task than expected and the difficulties which chemistry encountered in its attempts at formalising quality persisted long into the twentieth century. ${ }^{102}$ After WWI the "quality" of flour came to be increasingly formalised through a variety of tests and instruments, but chemical analyses of flour were mostly superseded by physical tests (viscosity, plasticity, ductility, etc.), especially through the use of Chopin's extensimeter (1921), still in use today. ${ }^{103}$ An analysis of interwar developments is beyond the scope of this article, but one may simply note here that even then, the new regime was clearly not exempt from doubts and contestations: actors in the grain trade, as exemplified with the Office National du Blé in France in the 1930s, still did not include a formal appreciation of strength in transactions and the questions of how to measure and guarantee the nutritional and baking qualities of wheat and bread were still far from stabilised and consensual. ${ }^{104}$ Just like in the nineteenth century, the scientists trying to simplify the criteria to assess the quality of wheat and flour and to predict its nutritional and baking properties constantly had to confront the complexity of the materiality of wheat, which opposed strong resistance to being reduced to a small set of numerical indicators.

102 Aashish Velkar, "Measurement Systems as Market Foundation: Perspectives from Historical Markets”, in The Manufacturing of Markets: Legal, Political and Economic Dynamics eds. Eric Brousseau \& Jean Michel Glachant (Cambridge: Cambridge University Press, 2014), 24.

103 Marcel Chopin, “Relation entre les propriétés mécaniques des pâtes de farine et la panification”, Bulletin de la société d'encouragement pour l'industrie nationale 133 (1921): 261-273; E. A. Fisher \& P. Halton, “An Examination of the Claim that the Swelling of Gluten in Acid Solution is a Satisfactory Foundation for the Evaluation of Flour Quality”, Journal of the Society of of Chemical Industry 52 (1933): 91-97; John Percival, Wheat in Great Britain (Leighton, 1934); C. H. Bailey, "Physical tests of Flour Quality", Wheat Studies of the Food Research Institute 16 (1940): 243-290; Colin Wrigley, Ian Batey \& Diane Miskelly, Cereal Grains: Assessing and Managing Quality (Duxford: Woodhead, 2017); Pierre Barbade, Louis Pisani-Borg, Jean Duval, Contribution à l'étude de la qualité des blés et farines (Paris, 1935).

104 Bulletin de la Société scientifique d’hygiène alimentaire 22 (1934): 12-35 cited in Michel Cepede, "Le problème économique de la qualité”, Bulletin de la Société scientifique d'hygiène alimentaire et d'alimentation rationnelle de l'homme 23 (1935): 102- 120 ; Anne-Marie Frenheard, “L’ONIC et la qualité du blé et du pain (1936-1957)", in Organiser les marchés agricoles, eds. Alain Chatriot, Edgar Leblanc, Édouard Lynch (Paris: Armand Colin, 2012), 255-272. 